Diana Maksimiuk

\title{
Dokument archiwalny dotyczący „uporządkowania” przez władzę ludową prawodawstwa w powojennej Polsce
}

\section{Wprowadzenie}

Prezentowany poniżej dokument to przygotowany najpóźniej 14 listopada 1944 r. w resorcie sprawiedliwości projekt dekretu o uporządkowaniu prawodawstwa Rzeczypospolitej Polskiej. Motywy sporządzenia tego aktu, a także prace nad nim i jego losy nie są mi znane. Wiadomo tylko, że w tym czy też w podobnym kształcie nie stał się aktem prawnym powszechnie obowiązującym.

Nowa władza, która powstała w Polsce po drugiej wojnie światowej, szukała podstawy legalności dla swego istnienia mimo rewolucyjnego $\mathrm{z}$ natury pochodzenia. Współczesna historiografia polska jest raczej zgodna, iż do osiągnięcia tego celu posłużyło jej odwołanie się do Konstytucji marcowej z równoczesnym odrzuceniem Konstytucji kwietniowej, uznawanej przez emigracyjny rząd w Londynie ${ }^{1}$. Władza ludowa uczyniła to, dokonując w Manifeście PKWN² opatrzonym datą 22 lipca 1944 r. zapisu, iż „Krajowa Rada Narodowa i Polski Komitet Wyzwolenia Narodowego działają na podstawie konstytucji z 17 marca $1921 \mathrm{r}$. jedynie obowiązującej konstytucji legalnej, uchwalonej prawnie. Podstawowe założenia konstytucji z 17 marca 1921 r. obowiązywać będą aż do zwołania wybranego w głosowaniu powszechnym, powszechnym bezpośrednim, równym,

1 Zob. m.in. A. Stawarska-Rippel, Prawo sądowe Polski Ludowej 1944-1950 a prawo Drugiej Rzeczypospolitej, Katowice 2006, s. 21; M. Kallas, Ustrój Polski Ludowej (1944-1989), [w:] M. Kallas, A. Lityński, Historia ustroju i prawa Polski Ludowej, Warszawa 2003, s. 43; W. Roszkowski, Najnowsza historia Polski 1918-1980, Londyn 1989, s. 446; M. Turlejska, Spór o Polskę. Szkice historyczne, Warszawa 1972, s. 328; K. Kersten, PKWN 22 VII-31 XII 1944 r., Lublin 1965, s. 68; W. Góra, Powstanie władzy ludowej w Polsce, Warszawa 1972, s. 77.

2 Załącznik do Dz.U. z 1944 r., nr 1. 
tajnym i stosunkowym Sejmu Ustawodawczego, który uchwali, jako wyraziciel woli narodu, nową konstytucję". Cytowane treści Manifestu wzbudziły od razu szereg wątpliwości i sporów, które próbowała w drugiej połowie lat czterdziestych rozstrzygnąć ówczesna nauka prawa ${ }^{3}$. Pierwsza kwestia sporna dotyczyła źródła obowiązywania Konstytucji marcowej po wojnie. Zastanawiano się, czy podstawą jej obowiązywania był fakt, że zawsze obowiązywała, bo nigdy nie została legalnie uchylona, i Manifest tylko stwierdzał ten fakt, czy też jedyną właściwą podstawą obowiązywania Konstytucji marcowej była decyzja ustrojodawcza rewolucyjnej władzy. Druga kwestia, co do której nie było zgodności, dotyczyła z kolei zakresu obowiązywania Konstytucji marcowej, a ściślej tego, czy obowiązywać miała cała konstytucja, czy też pewne jej fragmenty. Dyskusja w tej drugiej kwestii stanowiła konsekwencję niesprecyzowania w żadnym akcie terminu „podstawowe założenia” ani „demokratyczne podstawowe zasady Konstytucji Marcowej”.

Żadnej wątpliwości nie budziło wówczas tylko całkowite odrzucenie Konstytucji kwietniowej. Manifest określał rząd londyński „władzą samozwańczą, władzą nielegalną”, a ustawę zasadniczą z 23 kwietnia 1935 r. uznawał za „bezprawną i faszystowską", opartą na politycznej motywacji. Zanegowanie Konstytucji kwietniowej spowodowało, że nowa władza stanęła przed kolejną kwestią, a mianowicie przed problemem stosunku do porządku prawnego II Rzeczypospolitej, jaki ukształtował się po 1935 r. Jak trafnie zauważyła A. Stawarska-Rippel: „Brak ustawowej regulacji dającej podstawę uznania za nieobowiązujące przepisów wydanych po 23 kwietnia 1935 roku i związanych z konstytucją kwietniową, a ponadto wyraźnego wskazania przepisów, które zostały uznane przez nową władzę za obowiązujące, oraz tych, których obowiązywanie zanegowano, był stanem, który wzmagał chaos prawny"4. Z tym niewątpliwie trudnym problemem władza ludowa chyba nie wiedziała za bardzo co uczynić. Prezentowany projekt dekretu stanowil, w mojej opinii, próbę rozwiązania tego zagadnienia.

3 Zob. A. Stawarska-Rippel, op. cit., s. 31-34; K. Działocha, J.Trzciński, Zagadnienie obowiązywania konstytucji marcowej w Polsce Ludowej 1944-1952, Wrocław-Warszawa-Kraków-Gdańsk 1977, s. 98 $-131$.

A. Stawarska-Rippel, op. cit., 39. 


\title{
DOKUMENT
}

\author{
1944 [listopad 14], [Lublin] - Projekt dekretu \\ o uporządkowaniu prawodawstwa Rzeczypospolitej Polskiej.
}

\author{
Projekt dekretu ${ }^{\mathrm{a}}$ \\ o uporządkowaniu prawodawstwa Rzeczypospolitej Polskiej, \\ z dnia ........ 1944 r. ${ }^{\mathrm{b}}$
}

Art. 1.

W numerze 30 Dziennika Ustaw Rzeczypospolitej z roku 1935 pod poz. 227 została ogłoszona "ustawa konstytucyjna z 23.4.1935." Ponieważ opublikowanie tego aktu w Dzienniku Ustaw pogwałciło art. 125 ust. 1 konstytucji z 17.3.1921 (Dz.U.R.P. Nr. 44 z roku 1921 poz. 267), bowiem przy uchwalaniu opublikowanego aktu ustawowego na sali obrad Sejmu nie była obecna wymagana połowa ustawowej liczby posłów, przeto opublikowany w Nrze 30/35 Dz.Ust. poz. 227 akt ustawodawczy jest sam przez się nieważny, stanowi zamach stanu i w związku z tym wszystkie akty prawodawcze wydane w postaci ustaw i dekretów na mocy wzmiankowanej nielegalnej konstytucji są nieważne.

Art. 2.

Ta sama nieważność dotyczy opublikowanych w Dzienniku Ustaw rozporządzeń wykonawczych do nieważnych uchwał wydanych na zasadzie aktu z 23.4.1935.

Art. 3.

Wyjątek stanowią wszelkie międzypaństwowe ${ }^{c}$ konwencje, układy, oświadczenia, protokóły, porozumienia, umowy handlowe, rozporządzenia Prezydenta Rzeczypospolitej i inne publikacje rządowe w Dzienniku Ustaw.

Art. 4.

Ważnymi są również wszelkie rozporządzenia i obwieszczenia rządowe opublikowane w Dzienniku Ustaw jeżeli są oparte na podstawie ustaw i rozporządzeń Prezydenta Rzeczypospolitej datowanych przed zamachem stanu z 23.4.1935 r.

$-2-$

Art. 5.

W powodzi nieważnych aktów prawodawczych opublikowanych w Dzienniku Ustaw w okresie po zamachu stanu z 23.4.1935 aż do 5 września 1939 r., znajdują się jednak akty prawodawcze mające istotne znaczenie dla życia. Te poszczególne akty będą w prawodawstwie Polski powoływane i tym samym będzie tym aktom nadawana moc prawna.

Źródło: AAN, Ministerstwo Sprawiedliwości, 5451, k. 1-2, oryginał, mps.

\footnotetext{
${ }^{a}$ Powyżej z prawej strony pieczęć z datą 15. LIST. 1944.

${ }^{\mathrm{b}}$ Poniżej z lewej strony odręcznie wpisana dekretacja Ustawod 14 XI 44 oraz nieczytelny podpis.

' Stowo podkreślone odręcznie.
} 